\title{
Highlight report: New applications of chimeric mice with humanized livers
}

\author{
Wiebke Albrecht ${ }^{1}$
}

Received: 15 November 2018 / Accepted: 19 November 2018 / Published online: 23 November 2018

c) Springer-Verlag GmbH Germany, part of Springer Nature 2018

Some years ago, chimeric mice with humanized livers have been introduced as a tool to study human drug metabolism (Strom et al. 2010; Kamimura et al. 2010; Scheer and Wilson 2016). These models make use of mice with genetic modifications that cause the deterioration of native hepatocytes (Strom et al. 2010). Most commonly, immunodeficient mice with a knockout of fumarylacetoacetate hydrolase or with overexpression of urokinase-type plasminogen activator are used for this purpose. When human hepatocytes are transplanted into these mice, they repopulate the host liver and may replace up to $95 \%$ of the murine hepatocytes. It has been reported that humanized mouse livers show some features of human gene expression patterns and mirror responses of human liver to hepatotoxic drugs (Go 2018). In a recent issue of the Archives of Toxicology, Anja Ekdahl and colleagues used chimeric mice with humanized livers to study the metabolism of fenclozic acid (Ekdahl et al. 2018). Fenclozic acid was developed as an alternative to high-dose therapy with aspirin (Chalmers et al. 1969a, b). Although fenclozic acid showed a good safety profile in experimental animals, it had to be withdrawn from late-stage clinical development because of hepatotoxicity (Ekdahl et al. 2018; Alcock 1970; Hart et al. 1970). The study was performed following oral administration of $10 \mathrm{mg}$ fenclozic acid per $\mathrm{kg}$ body weight in bile-cannulated humanized mice (Ekdahl et al. 2018). Interestingly, the authors were able to detect human-specific metabolites, such as fenclozic acid with side-chain extension in plasma and excreta, and could establish differences in metabolic patterns compared to conventional mice.

The use of chimeric humanized mice is attractive because it offers the possibility to study human hepatocytes in the environment of an organ in vivo. Nevertheless, many

Wiebke Albrecht

albrecht@ifado.de

1 IfADo-Leibniz Research Centre for Working Environment and Human Factors at TU Dortmund, Ardeystr. 67,

44139 Dortmund, Germany questions concerning this innovative mouse model remain open. For example, it is well known that isolation and cultivation of hepatocytes cause major changes in cell function and gene expression (Godoy et al. 2009, 2015, 2016a, b, 2018; Zellmer et al. 2010; Grinberg et al. 2014). It remains open to which degree the transplanted human hepatocytes differ when transplanted into mouse livers compared to their state in the human microenvironment. A well-established alternative system to humanized mouse livers is cultivated human hepatocytes ( $\mathrm{Gu}$ et al. 2018; Deharde et al. 2016; Reif et al. 2015; Ghallab et al. 2016; Kim et al. 2015; Frey et al. 2014), a cell system well established for the purpose of metabolite generation and identification (Hewitt et al. 2007; Godoy et al. 2013).

Unfortunately, little is known about the metabolic capacity of cultivated human hepatocytes compared to their performance in chimeric mouse livers. An obvious advantage of the humanized mice is that both biliary as well as renal excretion can be studied. Bile canaliculi form a complex network that is linked to the interlobular ducts and drains bile to larger ducts and the gall bladder (Vartak et al. 2016). After induction of hepatotoxicity, both canaliculi and bile ducts show major structural changes (Jansen et al. 2017). In chimeric mice, bile canaliculi can be expected to be formed by the apical cell membranes of the human hepatocytes and these structures have to link to the ducts that are formed by mouse cholangiocytes. It would be interesting to learn more about the architecture of these chimeric biliary tracts and whether they recapitulate cholestatic structural changes observed in normal livers. It still has to be established, whether basolateral and apical transport mechanisms known from mice and humans (Reif et al. 2017; Köppert et al. 2018) are maintained in the chimeric animals.

In conclusion, mice with humanized livers represent a fascinating model system but more basic work is required to obtain a better understanding of its possibilities and limitations. 


\section{Compliance with ethical standards}

Conflict of interest The author declares that she has no conflict of interest.

\section{References}

Alcock NW (1970) Comparative aspects of bone and calcifying cartilage. Calcif Tissue Res 1970:130-131 (No abstract available)

Chalmers TM, Kellgren JH, Platt DS (1969a) Evaluation in man of fenclozic acid (I.C.I. 54,450: Myalex), a new anti-inflamatory agent. II. Clinical trial in patients with rheumatoid arthritis. Ann Rheum Dis 28(6):595-601

Chalmers TM, Pohl JE, Platt DS (1969b) Evaluation in man of fenclozic acid (I.C.I. 54,450: Myalex), a new anti-inflammatory agent. I. Serum concentration studies in healthy individuals and in patients with rheumatoid arthritis. Ann Rheum Dis 28(6):590-594

Deharde D, Schneider C, Hiller T et al (2016) Bile canaliculi formation and biliary transport in 3D sandwich-cultured hepatocytes in dependence of the extracellular matrix composition. Arch Toxicol 90(10):2497-2511

Ekdahl A, Weidolf L, Baginski M, Morikawa Y, Thompson RA, Wilson ID (2018) The metabolic fate of fenclozic acid in chimeric mice with a humanized liver. Arch Toxicol 92(9):2819-2828. https://doi.org/10.1007/s00204-018-2274-0

Frey O, Misun PM, Fluri DA, Hengstler JG, Hierlemann A (2014) Reconfigurable microfluidic hanging drop network for multitissue interaction and analysis. Nat Commun 5:4250. https://doi. org/10.1038/ncomms5250

Ghallab A, Cellière G, Henkel SG et al (2016) Model-guided identification of a therapeutic strategy to reduce hyperammonemia in liver diseases. J Hepatol 64(4):860-871. https://doi.org/10.1016/j. jhep.2015.11.018

Go Y (2018) Utility of humanized liver mouse model in evaluation of mitochondrial transporters-associated hepatotoxicity. Drug Metab Pharmacokinet 33:S11. https://doi.org/10.1016/j. dmpk.2017.11.054

Godoy P, Hengstler JG, Ilkavets I et al (2009) Extracellular matrix modulates sensitivity of hepatocytes to fibroblastoid dedifferentiation and transforming growth factor beta-induced apoptosis. Hepatology 49(6):2031-2043. https://doi.org/10.1002/hep.22880

Godoy P, Hewitt NJ, Albrecht U et al (2013) Recent advances in 2D and $3 \mathrm{D}$ in vitro systems using primary hepatocytes, alternative hepatocyte sources and non-parenchymal liver cells and their use in investigating mechanisms of hepatotoxicity, cell signaling and ADME. Arch Toxicol 87(8):1315-1530

Godoy P, Schmidt-Heck W, Natarajan K et al (2015) Gene networks and transcription factor motifs defining the differentiation of stem cells into hepatocyte-like cells. J Hepatol 63(4):934-942. https ://doi.org/10.1016/j.jhep.2015.05.013 (Erratum in: J Hepatol. 2016)

Godoy P, Schmidt-Heck W, Natarajan K et al (2016a) Gene networks and transcription factor motifs defining the differentiation of stem cells into hepatocyte-like cells. J Hepatol 63(4):934-942. https ://doi.org/10.1016/j.jhep.2015.05.013 (Erratum in: J Hepatol. 2016)
Godoy P, Widera A, Schmidt-Heck W et al (2016b) Gene network activity in cultivated primary hepatocytes is highly similar to diseased mammalian liver tissue. Arch Toxicol 90(10):2513-2529

Godoy P, Schmidt-Heck W, Hellwig B et al (2018) Assessment of stem cell differentiation based on genome-wide expression profiles. Philos Trans R Soc Lond B Biol Sci 373(1750):20170221. https://doi.org/10.1098/rstb.2017.0221.Review

Grinberg M, Stöber RM, Edlund K et al (2014) Toxicogenomics directory of chemically exposed human hepatocytes. Arch Toxicol 88(12):2261-2287

Gu X, Albrecht W, Edlund K et al (2018) Relevance of the incubation period in cytotoxicity testing with primary human hepatocytes. Arch Toxicol. https://doi.org/10.1007/s00204-018-2302-0 (Epub ahead of print)

Hart FD, Bain LS, Huskisson EC, Littler TR, Taylor RT (1970) Hepatic effects of fenzlozic acid. Ann Rheum Dis 29(6):684

Hewitt NJ, Lechón MJ, Houston JB et al (2007) Primary hepatocytes: current understanding of the regulation of metabolic enzymes and transporter proteins, and pharmaceutical practice for the use of hepatocytes in metabolism, enzyme induction, transporter, clearance, and hepatotoxicity studies. Drug Metab Rev 39(1):159-234 (Review)

Jansen PL, Ghallab A, Vartak N, Reif R, Schaap FG, Hampe J, Hengstler JG (2017) The ascending pathophysiology of cholestatic liver disease. Hepatology 65(2):722-738

Kamimura H, Nakada N, Suzuki K et al (2010) Assessment of chimeric mice with humanized liver as a tool for predicting circulating human metabolites. Drug Metab Pharmacokinet 25(3):223-235

Kim JY, Fluri DA, Marchan R et al (2015) 3D spherical microtissues and microfluidic technology for multi-tissue experiments and analysis. J Biotechnol 205:24-35. https://doi.org/10.1016/j.jbiot ec.2015.01.003

Köppert S, Büscher A, Babler A et al (2018) Cellular clearance and biological activity of calciprotein particles depend on their maturation state and crystallinity. Front Immunol 9:1991. https://doi. org/10.3389/fimmu.2018.01991 (eCollection 2018)

Reif R, Karlsson J, Günther G et al (2015) Bile canalicular dynamics in hepatocyte sandwich cultures. Arch Toxicol 89(10):1861-1870

Reif R, Ghallab A, Beattie L, Günther G, Kuepfer L, Kaye PM, Hengstler JG (2017) In vivo imaging of systemic transport and elimination of xenobiotics and endogenous molecules in mice. Arch Toxicol 91(3):1335-1352. https://doi.org/10.1007/s00204-016-1906-5

Scheer N, Wilson ID (2016) A comparison between genetically humanized and chimeric liver humanized mouse models for studies in drug metabolism and toxicity. Drug Discov Today 21(2):250-263. https://doi.org/10.1016/j.drudis.2015.09.002 (Epub 2015 Sep 7)

Strom SC, Davila J, Grompe M (2010) Chimeric mice with humanized liver: tools for the study of drug metabolism, excretion, and toxicity. Methods Mol Biol 640:491-509. https://doi.org/10.1007/9781-60761-688-7_27 (Review)

Vartak N, Damle-Vartak A, Richter B, Dirsch O, Dahmen U, Hammad S, Hengstler JG (2016) Cholestasis-induced adaptive remodeling of interlobular bile ducts. Hepatology 63(3):951-964

Zellmer S, Schmidt-Heck W, Godoy P et al (2010) Transcription factors ETF, E2F, and SP-1 are involved in cytokine-independent proliferation of murine hepatocytes. Hepatology 52(6):2127-2136. https://doi.org/10.1002/hep.23930 